\title{
Faktor yang Mempengaruhi Persepsi Kemudahan dan Kemanfaatan Penggunaan Sistem Informasi Manajemen RSU Kaliwates Jember Tahun 2019
}

\section{(Factors Affecting Perception of Ease and Benefit of Using Management Information Systems at Kaliwates Hospital, Jember 2019)}

\author{
Famela Niken Arista Furi, Christiyana Sandra, Eri Witcahyo \\ Peminatan Administrasi Kebijakan Kesehatan,Program Studi S1 Kesehatan Masyarakat, Fakultas \\ Kesehatan Masyarakat, Universitas Jember \\ e-mail korespondensi: famelaniken30@gmail.com
}

\begin{abstract}
Kaliwates General Hospital is a privately owned public service body with full accreditation status for five services and was established by the Ministry of Health of the Republic of Indonesia on December 31, 2010, No.Y.M.01.10/III/7957/10. At the beginning of its development, Kaliwates General Hospital managed data and information using still manual systems. In 2012 Kaliwates General Hospital began using computerized management information systems and changed vendors in 2015. This research is an analytical study with an observational approach. In this study, researchers tested hypotheses on the influence of institutional factors, social factors, and individual factors independently and together influenced the perceived ease and prestige of the usefulness of information systems. Institutional factors, social factors, individual factors, and ease of use significantly affect perceived usefulness in the Kaliwates general hospital management information system.
\end{abstract}

Keywords: perception of ease, information system, management information system

\begin{abstract}
Abstrak
Rumah Sakit Umum Kaliwates (RSUK) merupakan badan layanan umum milik swasta dengan status akreditasi penuh untuk lima pelayanan dan ditetapkan oleh Kementerian Kesehatan RI pada tanggal 31 Desember 2010 dengan No. Y.M.01.10/II/7957/10. Pada awal masa perkembangannya, RSUK masih menggunakan sistem manual dalam pengelolaan data dan informasi. Pada tahun 2012, RSUK mulai menggunakan system informasi manajemen yang terkomputerisasi dan berganti vendor pada tahun 2015. Penelitian ini bertujuan untuk mengethaui pengaruh faktor institusional, faktor social, dan faktor individu baik secara mandiri maupun Bersama-sama dalam mempengaruhi persepsi kemudahan dan persepsi kemanfaatan penggunaan sistem informasi. Penelitian ini merupakan penelitian analitik dengan pendekatan observasional. Hasil penelitian menunjukkan bahwa faktor institusional, faktor social, dan faktor individu, dan kemudahan penggunaan berpengaruh signifikan terhadap kemanfaatn penggunaan pada sistem informasi manajemen (SIM) RSUK Kaliwates.
\end{abstract}

Kata kunci: persepsi kemudahan, sistem informasi, system informasi manajemen. 


\section{Pendahuluan}

Rumah sakit merupakan suatu organisasi yang bergerak di bidang pelayanan kesehatan yang kompleks, padat aturan, padat profesi, dan padat teknologi. Penerapan sistem informasi di rumah sakit diatur dalam PERMENKES No. 82 Tahun 2013 tentang sistem informasi manajemen rumah sakit yang menyatakan bahwa sesuai dengan UU No. 44 Tahun 2009, setiap rumah sakit wajib melakukan pelaporan dan pencatatan atas semua kegiatan penyelenggaraan rumah sakit dalam bentuk sistem informasi manjeman rumah sakit (SIM-RS) [1].

Sistem informasi memiliki 3 peranan penting dalam mendukung proses pelayanan kesehatan, yaitu: mendukung proses dan operasi pelayanan kesehatan, mendukung pengambilan keputusan staf dan pemimpin serta mendukung berbagai strategi untuk keunggulan kompetitif. Penggunaan teknologi informasi modern ini memberikan peluang yang besar untuk mengurangi kesalahan klinis misalnya kesalahan pengobatan, kesalahan diagnostik, untuk mendukung pelayanan kesehatan profesional seperti ketersediaan waktu, informasi update pasien, untuk meningkatkan efisiensi perawatan seperti waktu tunggu pasien, dan untuk meningkatkan kualitas pelayanan pasien. Untuk menambah atau mengurangi ketidakpastian pemakai informasi merupakan fungsi utama dari informasi [2].

Kesenjangan informasi tidak akurat dan memperlambat laju informasi. Sehingga, akan memperlambat dalam pengambilan keputusan. Informasi adalah data yang diolah menjadi bentuk yang lebih berguna dan lebih berarti bagi yang menerimanya. Adapun kualitas informasi tergantung dari 3 hal yang sangat dominan yaitu relevansi, ketepatan waktu, dan keakuratan informasi [3].

Menurut Agarwal (dalam Jogiyanto, 2007)[4,5], penerimaan teknologi oleh pemakai individual tidak terlepas dari kepercayaankepercayaan (beliefs) pemakai terhadap teknologinya. Kepercayaan-kepercayaan (beliefs) mewakili struktur-struktur kognitif yang dikembangkan oleh individu setelah mengumpulkan, memproses, dan mensintesis informasi tentang teknologi informasi, dan memasukkan penilaian-penilaian individual dari bermacam-macam hasil (outcomes) yang berkaitan dengan penggunaan teknologinya. Kepercayaan-kepercayaan (beliefs) telah menunjukkan mempunyai dampak yang mendalam terhadap perilaku-perilaku individu. Dengan demikian proses pembentukan kepercayaan ini menarik untuk diteliti lebih lanjut.

Di penelitian perilaku penerimaan teknologi (termasuk TAM), dua buah variabel kepercayaan-kepercayaan (beliefs) digunakan, yaitu; kegunaan persepsian (perceived usefulness) meliputi kepercayaan-kepeтcayaan (beliefs) dipersepsikan mengenai manfaat dari penggunaan teknologi dan kemudahan penggunaan persepsian (perceived ease of use), yaitu kepercayaan kepercayaan (beliefs) bahwa menggunakan teknologi tidak banyak dibutuhkan usaha. Kedua konstruk kepercayaan kepercayaan (beliefs) ini dipercaya mempengaruhi perilaku penerimaan teknologinya. Lewis et al. (2003) membentuk suatu model yang menunjukkan kedua kepercayaan-kepercayaan (beliefs) ini dipengaruhi oleh faktor-faktor individual, institusional dan sosial.

\section{Metode Penelitian}

Jenis penelitian ini merupakan penilitian analitik dengan peendekatan observasional. Tempat penelitian dilaksanakan di Rumah Sakit Umum (RSU) Kaliwates Jember pada bulan JuliOktober 2020. Sumber data penelitian yaitu data primer hasil wawancara dan data sekunder berupa profil rumah sakit, data jumlah, nama dan bagian pengguna SIM-RS. Teknik pengumpulan data dengan melakukan wawancara secara langsung kepada responden yaitu pengguna SIM-RS RSU Kaliwates menggunakan lembar kuesioner [6].

Data yang diperoleh dari hasil wawancara yang akan disajikan dalam bentuk tabel distribusi frekuensi dan kemudian dijelaskan dalam bentuk narasi. Teknik pengolahan data pada penelitian ini yaitu editing, scoring, dan tabulating. Analisis data dalam penelitian ini menggunakan analisis regresi untuk meneliti seberapa besar pengaruh dua variabel bebas terhadap variabel terikat dilihat dari nilai koefisien determinasi R Square.

\section{Hasil Penelitian}

Berdasarkan hasil penelitian faktor yang mempengaruhi persepsi kemudahan dan kemanfaatan penggunaan teknologi SIM-RS RSU Kaliwates Jember menunjukan hasil output analisis multivariat dalam tabel Result (Default model) memunculkan kata Minimum was achieved dan degrees of freedom bernilai dua positif maka proses model sudah dapat dilakukan. Oleh karena df positif dan kalimat "Minimum was achieved" pada output software uji, proses pengujian telah dapat dilakukan, Dengan probability level $=0.006$ dapat menggunakan jenis identifikasi Just identified.

Hasil penelitian faktor yang mempengaruhi persepsi kemudahan dan kemanfaatan penggunaan teknologi SIM-RS 
RSU Kaliwates Jember menunjukan hasil output analisis multivariat dalam tabel Result (Default model) memunculkan kata Minimum was achieved dan degrees of freedom bernilai dua positif maka proses model sudah dapat dilakukan. Karena df positif dan kalimat "Minimum was achieved" pada output software uji, proses pengujian telah dapat dilakukan, Dengan probability level $=0.006$ dapat menggunakan jenis identifikasi Just identified. Dalam terminologi SEM dinamakan saturated [6].

Hasil Regression Weight menjelaskan pengaruh dari variabel yang diteliti. Validitas data dapat dilihat dari hasil kalkulasi alat statistik SPSS AMOS menunjukan nilai $P$ menunjukan tanda ${ }^{* * *}$ yang berarti pengaruh menunjukan taraf signifikansi dibawah 0,01 atau sangat signifikan. Analisis faktor yang mempengaruhi persepsi kemudahan dan kemanfaatan penggunaan teknologi SIM-RS RSU Kaliwates Jember menggunakan taraf kepercayaan 0,05 yang berarti nilai $\mathrm{P}$ apabila menunjukan hasil dibawah 0,05 masih menunjukan nilai yang signifikan, namun apabila nilai $P$ diatas 0,05 berarti tidak signifikan.

\section{Pembahasan}

Pada penelitian ini, dilakukan analisis factor-faltor yang mempengaruhi persepsi kemudahan dan kemanfaatn penggunaan teknologi SIM-RSUK Jember. Analisis multivariat menunjukkan Result (Default model) memunculkan kata Minimum was achieved dan degrees of freedom bernilai dua positif maka proses model sudah dapat dilakukan. Hal ini sesuai dengan pernyataan Santoso (2015) karena df positif dan kalimat "Minimum was achieved" pada output software uji, proses pengujian telah dapat dilakukan, Dengan probability level $=0.006$ dapat menggunakan jenis identifikasi Just identified [7].

Faktor-faktor yang mempengaruhi persepsi kemudahan dan kemanfaatn penggunaan teknologi SIM-RSUK, Jember menunjukan hasil output analisis multivariat dalam tabel Result (Default model) memunculkan kata Minimum was achieved dan degrees of freedom bernilai dua positif maka proses model sudah dapat dilakukan. Hal ini sesuai dengan pernyataan Santoso (2015:61) karena df positif dan kalimat "Minimum was achieved" pada output software uji, proses pengujian telah dapat dilakukan, Dengan probability level $=0.006$ dapat menggunakan jenis identifikasi Just identified. Dalam terminologi SEM dinamakan saturated [7].

Persepsi responden tentang kemanfaatan penggunaan teknologi SIM-RS RSU Kaliwates Jember dipengaruhi oleh faktor institusional, tetapi tidak dipengaruhi oleh factor sosial karena pengguna merasa bertanggungjawab terhadap manajemen rumah sakit dibanding dengan rekan kerja sehingga faktor sosial tidak mempengaruhi pengguna dalam menggunakan SIM-RS. Pengguna cenderung berkonsultasi langsung kepada Admin apabila terdapat kendala dalam penggunaan SIM-RS.

Faktor individu juga tidak mempengaruhi persepsi responden tentang kemanfaatan penggunaan teknologi SIM-RSUK, Jember karena dalam penerapan SIM-RS sudah menjadi aturan pihak Manajemen Rumah Sakit sehingga penggunaan SIM-RS lebih menjadi tanggung jawab yang sudah diharuskan bukan dari manfaatnya.

Persepsi responden tentang kemudahan penggunaan teknologi SIM-RS RSU Kaliwates Jember dipengaruhi faktor individu dan persepsi kemudahan penggunaan teknologi SIM-RS RSUK, Jember.

\section{Simpulan dan Saran}

Hasil penelitian menyimpulkan bahwa persepsi responden tentang kemanfaatan penggunaan teknologi SIM-RSU Kaliwates Jember dipengaruhi oleh faktor institusional. Tetapi tidak dipengaruhi oleh faktor sosial dan faktor individu. Sedangkan persepsi responden tentang kemudahan penggunaan teknologi SIMRSU Kaliwates Jember dipengaruhi faktor individu dan

persepsi kemudahan penggunaan teknologi SIMRS RSU Kaliwates Jember.

\section{Daftar Pustaka}

[1] Menkes RI. 2013. Keputusan Menteri Kesehatan Republik Indonesia Nomor 82. Tentang Sistem Informasi Manajemen Rumah Sakit. Jakarta: Kementerian Republik Indonesia

[2] Sutabri, Tata. 2016b. Sistem Informasi Manajemen. Yogyakarta. Andi Offset.

[3] Kadir, 2003. Pengenalan Sistem Informasi. Yogyakarta: ANDI Yogyakarta.

[4] Jogiyanto, 2007a. Model Kesuksesan Sistem Teknologi Informasi. Yogyakarta: Penerbit ANDI.

[5] Jogiyanto, 2007b. Sistem Informasi Keperilakuan. Yogyakarta: Penerbit ANDY.

[6] Notoatmodjo, S., $2005 . \quad$ Metodologi Penelitian Kesehatan. Jakarta: Rineka Cipta.

[7] Santoso S. 2015. AMOS 22 untuk Structural Equation Modeling. Jakarta: PT. Elex Media Komputindo. 